\title{
The Key Drivers for the Digitalization of the Supply Chain
}

Stavros Ioannis Valsamidis, Department of Accounting and Finance, International Hellenic University, Kavala, Greece iD https://orcid.org/0000-0001-7398-9073

\begin{abstract}
The digital supply chain is a reality since markets are demanding efficiency, agility, and flexibility for modern supply chains. Digitalization can have a major impact on the supply chain. The aim of the study is to deepen the knowledge and understanding of the digitalization of the supply chain. It explores executives' attitudes towards the use of trends and technologies in supply chain. It identifies the factors that affect executives' attitudes towards those trends and technologies, and it classifies them into groups according to their similar behaviour patterns and profiles each group of respondents according to the characteristics of their companies. The main factors are mobility, human factors, and pricing. Characteristics such as type of company, year of establishment, number of employees, technological infrastructure have an impact on executives' behaviour. The survey revealed a few noteworthy findings that may influence companies for resource reallocation and strategically shift resources to create more value and deliver higher returns to shareholders.
\end{abstract}

\section{KEYWORDS}

Digitalization, Factor Analysis, Principal Components Analysis, Regression Analysis, Supply Chain

\section{INTRODUCTION}

Industry 4.0 is defined as the next phase in the digitization of the manufacturing sector, driven by the astonishing rise in data volumes, computational power, and connectivity, especially new low-power wide-area networks; the emergence of analytics and business-intelligence capabilities; new forms of human-machine interaction such as touch interfaces and augmented-reality systems; and improvements in transferring digital instructions to the physical world, such as advanced robotics and 3-D printing (Roblek et al., 2016; McKinsey Special Collection Digital strategy, 2017). The term describes "the forth industrial revolution, a new step of organization and management of whole supply chains over the life cycle of products" (Platform I4.0, 2015). The biggest impact from the Industry 4.0 technologies and concepts is to be expected from a technological view especially for the procurement, production and distribution activities in the supply chain (Kersten et al., 2015).

Industry 4.0 is not limited to the technical dimension of digitalizing modern businesses, as it is rather the complete new organization and network coordination of value and supply chains (Glas and Kleemann, 2016). Industry 4.0 is expected to form in its ultimate shape new digitalized supply ing on February 1, 2021 in the gold Open Access journal, International Journal of Operations Research and Information Systems (converted to gold Open Access January 1, 2021), and will be distributed under the terms of the Creative Commons Attribution License (http://creativecommons.org/licenses/by/4.0/) which permits unrestricted use, distribution, and production in any medium, provided the author of the original work and original publication source are properly credited. 
chains, which shall realize collaborative productivity rents and ensure no less than the competitiveness of entire industries (Willems et al., 2018). Whilst many more companies are already investigating how to react to the current trend of implementing Industry 4.0 technologies and concepts, recent research with respect to this term is highly diverse and limited to the operational implementation of technologies and concepts on the production process-level (Herman et al., 2015).

The function of any supply chain centers on the movement of materials, finished goods, capital, and other assets from place to place, as well as the production of finished goods. A supply chain is the system of organizations, people, activities, information and resources involved in moving a product or service from supplier to customer. Supply chain activities transform raw materials and components into a finished product that is delivered to the end customer. At their core, however, supply chains consist of many transactions: the exchange of time, money, information, or physical materials for some other unit of value (Christopher, 2016).

Supply Chain Management is the design and management of processes across organizational boundaries with the goal of matching supply and demand in the most cost effective way. Dramatic technological and digital developments, such as greater computing power and lower overall costs, have impacted the traditional supply chain in several key ways, including a reduction in transaction costs and increase in innovation related to the production process itself (EY, 2017).

Supply chains traditionally are linear in nature, with a discrete progression of design, plan, source, make, and deliver. Today, however, many supply chains are transforming from a staid sequence to a dynamic, interconnected system that can more readily incorporate ecosystem partners and evolve to a more optimal state over time (Deloitte's Digital Supply Networks, 2016). This shift from linear, sequential supply chain operations to an interconnected, open system of supply operations could lay the foundation for how companies compete in the future (Specture Labs, 2018). Historically, supply chain professionals managed the "four Vs" (volatility, volume, velocity, and visibility) as they attempted to optimize results across a series of objectives that include total cost, service, quality, and support for innovation (Deloitte's Digital Supply Networks, 2016). For a number of industry sectors (retail, auto, electronic, aviation, chemical), digitalization of supply networks has been an important issue for more than two decades, but this concern is not shared across other industries (Hartmann et al., 2015).

The digitalisation of supply chain is the utilisation of digital technologies and processes to enable supply chains to be more effectively and efficiently managed, creating business networks and increasing the overall supply chain visibility within the network. Digital transformation can have a major impact on all parties across the supply chain. It can negatively impact the supply of materials from manufacturing plants through to the customers, as well as alter the flow of money (Alicke et al., 2016). Unfortunately, the cause of the disruption often goes unexposed until the repercussions actually occur. By then it may be too late to account for the changes that should have happened to prevent the disruption. This can lead to major financial problems, such as a devastating loss of revenue (Baxter, 2016).

The management needs to evaluate how their supply chain will be impacted by the relevant technologies, i.e. which challenges and potentials are to be expected with respect to the primary supply chain activities (Lambert, 2008). With the global supply chain poised to make dramatic shifts in the coming years to accommodate trends and gain deeper visibility into business processes in order to stay ahead of the competitive curve, every company throughout the value chain stands to benefit by adopting new technologies early and rethinking traditional, outdated processes to combat industry disruptors (Pontius, 2017). Firms work together in supply chains, but seek to maximize their individual power to capture greater value for themselves (Peppard \& Rylander, 2006).

Best-in-class supply chains are successfully combining enabling technologies to drive superior performance. With a strategic focus and the courage to collaborate, they are creating digital capabilities that give them the competitive advantage they need to survive and thrive in today's on-demand economy (Geissbauer et al., 2016). The general consensus is that companies cannot afford to wait 
and the leaders in digital supply chain management are building a financial advantage that will be more difficult to overcome with each passing year (Korn Ferry Institute, 2017).

Technology is the driver of this digitalization in supply chains, but it is not a single technology. The trends and the technologies include Predictive Analytics, Robotics and Automation, Sensors and Automatic Identification, Wearable and Mobile Technology, Driverless Vehicles and Drones, Inventory and Network Optimization Tools, Cloud Computing and Storage, 3D Printing, Autonomous trucks, and Blockchain applications in the supply chain (MHI, 2016). Especially, autonomous logistics, a driverless way of bringing goods from A to $\mathrm{B}$, will revolutionise the industry by eliminating dependency on the human factor. Data collected via sensors, (radio-frequency identification RFID), barcode and remote devices along the entire value chain will be a make-or-break capability (Accenture, 2017).

The aim of this study is to find out whether there is a relationship between the business digitalization and the supply chain, technology systems or other company features such as type of the company, year of establishment and number of employees.

This remainder of the paper is constructed as following: The second section describes the related work. The third section proposes the methodology. The fourth section presents the results of the empirical study section highlights the findings of the results and draws useful conclusions.

\section{RELATED WORK}

According to Santos and Eisenhardt (2005), the key motivation for supply chain integration is the efficiency associated with minimizing governance costs, including the costs of exchange with other ecosystem participants and with those within the individual organization.

Nowadays, as consumption and production are growing enormously fast, companies are seeking for costs reduction aimed at ensuring competitiveness. Supply chain expenses play a colossal role in the cost of the final product. The relationship between the supply chain expenses and the price of the final product, the classification of logistics chain costs and their minimization as an assumption for the competitiveness of the final price is presented by Lapinskaite \& Kuckailyte (2014).

According to McKinsey research, digitization has only begun to transform many industries (McKinsey Special Collection Digital strategy, 2017). Digital is penetrating all sectors, but to varying degrees (Bughin et al., 2017). The perception of respondents for the digital penetration by industry is $44 \%$ for travel, transport and logistics. Only 2 percent, in fact, report that supply chains are the focus of their forward-looking digital strategies, though headlining examples such as Airbnb and Uber demonstrate the power of tapping previously inaccessible sources of supply and bringing them to market.

The benefits of Digital Supply Chain (DSC) include cost-effectiveness of services and valuecreating activities that are advantageous to many actors in the ecosystem, including firms and their suppliers, employees and customers (Maier et al., 2011). According to Mentzer et al. (2001), a supply chain can be defined as a set of three or more entities (i.e., organizations or individuals) directly involved in the upstream and downstream flows of products, services, finance, and/or information from a source to a customer.

Supply chain management (SCM) encompasses the efforts involved in delivering and producing products and services in the value chain (Sherer, 2005). SCM links the processes across supplier-user companies and functions that enable the value chain to make products and provide services to the customer (Cox et al., 1995).

A study by The Boston Consulting Group shows that the leaders in digital supply chain management are enjoying increases in product availability of up to 10 percentage points, more than $25 \%$ faster response times to changes in market demand, and $30 \%$ better realization of working-capital reductions, on average, than the laggards (Korn Ferry Institute, 2018). They have $40 \%$ to $110 \%$ higher operating margins and $17 \%$ to $64 \%$ fewer cash conversion days. With the help of three key strategies, these agile companies are quickly leaving behind their less nimble competitors. The general consensus 
is that companies cannot afford to wait and the leaders in digital supply chain management are building a financial advantage that will be more difficult to overcome with each passing year. Companies will need to map opportunities for each of the newly available technologies. With digital transformation changing markets everywhere, top executives around the world are changing their priorities. Korn Ferry International surveyed 100 senior supply chain executives, along with interviewing academics and consultants, to explore issues that leaders face and their approach to building and organising the required talent to support this transformation. More than half of the respondents ( 53 percent) had a formal position to lead digital SCM, with most (92 percent) reporting to a Chief Operating Officer (COO), Chief Supply Chain Officer (CSCO), or to a supply chain leadership member. Digitisation is highly relevant for SCM, with three-quarters (74 percent) of executives rating this as 4 or 5 out of 5. Three out of four respondents said their organisations lack a clearly defined success profile for digital transformation of supply chain leaders, with many leaders suggesting that "we don't know how to improve our level of digitisation in supply chain".

McKinsey observes that most of the disparity between potential and actual gains from supply chain digitisation can be explained by technology gaps and poor management choices (McKinsey Special Collection Digital strategy, 2017). However, now that better digital solutions have become available, companies can make greater and faster improvements in supply-chain performance (Gezgin et al., 2017). According to Supply Chain Digital, 70 percent of executives have already begun digital supply chain transformation, yet progress is slow.

Capgemini Consulting and GT Nexus studied 337 executives from major global manufacturing and retail organizations across 20 countries throughout Europe and North America (Capgemini and GT Nexus, 2017). Exploring the relationship between organizations and their partners throughout the supply chain in their study, they remark that the first to examine both the current and future states of digital transformation across the supply chain. The survey found that half of the executives responding view digital transformation as very important ( 75 percent agree that digital transformation is at least 'important'), but more than 30 percent are dissatisfied with their progress to date. Just 15 percent of respondents to the survey indicate that data from the extended supply chain is readily available to their organizations, yet 54 percent expect improvements in availability within the next five years (Pontius, 2017). So, it is useful reading for most procurement people, particularly anyone in those sectors where supply chain is key, and it paints a picture of unmet need really in terms of the skills and talent available in this field. Three quarters of the 100 supply chain executives who participated in the study (through a survey and interviews) acknowledged that digitisation is highly relevant to their situation (KPMG, 2018). As the report says, "The function is expected to develop greater flexibility, lower cost and risk, and even develop new ways of analysing its potential revenue impact". But about four in 10 of those surveyed (41 percent) said a key barrier to digitising the supply chain was the availability of digital talent. Despite this, the "financial commitment to developing the required skills is low", with two thirds of executives saying that less than $10 \%$ of training budgets is relevant to digital, and that this amount is clearly not enough. Three-quarters of the sample positioned themselves in the middle of the pack, saying that a start has been made on digitisation, but there was still some way to go, with the "lack of a clear strategy" the biggest barrier to digital transformation. Lack of digital talent was a close second - that fits with our own thinking on general procurement transformation, where clarity of strategy has to come first, and then the "people aspects" really are the most critical success factor (Smith, 2018).

Traditional players in the logistics industry risk becoming irrelevant unless they embrace change in order to deliver more customer-centric services (Brightmore, 2018). DSC examines the findings of a new report by Accenture, which offers businesses advice on how to upgrade digital logistics strategies, calling on companies to raise their game and prepare to disrupt (Morley, 2017). However, according to the report by Accenture on digital disruption in freight and logistics, if traditional players embrace digital adoption and harness the power of new technologies to build new digital business models, they could not only enhance their competitiveness, but also boost earnings by approximately $13 \%$ per annum (Accenture, 2017). 


\section{METHODOLOGY}

\subsection{Sample}

In order to ascertain the views of experts on the digital transformation in supply chain, the views of supply chain management executives of 204 companies in the area of Northern Greece were recorded and processed. The respondents are executives who are responsible for SCM functions (i.e. Chief Supply Chain Officers) or executives whose responsibilities explicitly include SCM or indirectly, who had acquired SCM experience in their previous positions. $57.8 \%$ of the companies belong to production sector, $4.4 \%$ to packaging sector, $20.1 \%$ to retail sale sector and $17.6 \%$ to distribution sector. $13.7 \%$ of the companies have less than 10 employees, $28.4 \%$ up to 30 employees, $33.8 \%$ up to 50 employees, $14.2 \%$ up to 200 employees and $8.8 \%$ have more than 200 employees.

\subsection{Survey Instrument}

In order to achieve this goal, we composed a questionnaire for the purpose of collecting empirical data from companies in the region selected for the research. The questionnaire is structured since it has a strict order of questions. The questionnaire consists of four (4) sections of questions, each of which were matched with company features and views on the digital transformation of the company and includes totally 43 items. In section A there are 6 items about company information. In section $\mathrm{B}$ there are 14 items about incidence of certain supply chain management issues, in section C (ICT items) there are 11 items about technology systems that have been adopted by each company and in section D there are 12 items about digitalization. All items in sections B, C and D are in 5 point Likert scale where 1 corresponds to "not adopted at all" and 5 to "fully adopted". Since the aim of the study is to find out whether there is a relationship between the digital business and the supply chain, technology systems or other company features, the 12 items in D sector measure the digitalization.

Section B consists of 14 items about supply chain/logistic. In order to identify patterns in the relationships between these items (Table 1).

Table 1. Items of section B

\begin{tabular}{|l|l|}
\hline \multicolumn{1}{|l|}{$\#$} & \multicolumn{1}{|c|}{ Supply Chain Management Issues } \\
\hline 1. & Deliverables mistakenly \\
\hline 2. & Errors in checking and calculating inventory level in store or central warehouse \\
\hline 3. & Errors in calculating refunds \\
\hline 4. & Theft of products \\
\hline 5. & Exceeding the expiration date of a product \\
\hline 6. & Disposal / obsolescence of a product \\
\hline 7. & Maintain a higher level of inventory than what is necessary \\
\hline 8. & No products in the warehouse or shelf (out-of-stock) resulting in lost sales \\
\hline 9. & Lack of transparency in the supply chain resulting in the failure to monitor the product life cycle \\
\hline 10. & Inability to calculate the exact level of demand for a product \\
\hline 11. & Inability to harmonize orders to replenish a product with the exact amount of quantity actually required \\
\hline 12. & Commitment of human resources to find, classify and process information handled in the supply chain \\
\hline 13. & Insufficient use of equipment and supply chain management tools due to lack of information \\
\hline 14. & Ineligibility of promotional actions leading to a reduction in the level of sales \\
\hline
\end{tabular}


In order to identify patterns in the relationships between the items in section $\mathrm{B}$, a principal component analysis (PCA) was conducted on the 14 items with orthogonal rotation (varimax).

During the analysis, in sequential steps we drop out items 4 and 7 because in the first of them the maximum component value in the corresponding table was 0.373 , while in the second the maximum value of the component in the corresponding table was 0.343 .

The Kaiser-Meyer-Olkin measure verified the sample adequacy for the analysis, $(\mathrm{KMO}=0.802$, Bartlett's test of sphericity $\left.\mathrm{x}^{2}(66)=1249.757, \mathrm{p}<0.001\right)$, indicated that correlations between items were sufficiently large for PCA. An initial analysis was run to obtain eigenvalues for each component in the data. Two components had eigenvalues over Kaiser's criterion of 1 and in combination explained $68,178 \%$ of the variance. The scree plot showed inflexion that justify retaining of 2 two components in the final analysis.

In repeative steps we drop out items because in the first item, the Measure of Sampling Adequacy value in the Anti-image Matrix was very low (0.436) and the maximum value of the component value in the corresponding table was 0.386 , while in the second item the maximum value of the component in the corresponding table was 0.381 .

Finally, the items that cluster on the same components suggested that the first factor represent A-Incoming components and second factor represents B-outcoming components. Incoming denotes activities related to the input of the company while outcoming denotes activities related to the output of the company.

Subsequently, we create a new factor for each one of the above components, as the average value of the items that consists them. These factors are called A-Incoming and B-Outcoming. In order to check about validity and reliability of each one of these two new factors, we use Cronbach's A index. The value of Cronbach's A for factor A is 0.873 and for factor B 0.768 , which means that each factor is high reliable, in the sense of internal consistency.

In section C (ICT items), respondents should state whether 11 technology systems have been adopted by their company. These technology systems are presented in Table 2 . For each one of the

Table 2. Items of section C

\begin{tabular}{|l|l|}
\hline \multicolumn{1}{|c|}{$\#$} & \multicolumn{1}{c|}{ Technology System } \\
\hline 1. & Supply Chain Management (SCM) \\
\hline 2. & Customer Relationship Management (CRM) \\
\hline 3. & Partner Relationship Management (PRM) \\
\hline 4. & Enterprise Resource Planning (ERP) \\
\hline 5. & Warehouse Management Systems (WMS) \\
\hline 6. & Manufacturing Execution Systems (MES) \\
\hline 7. & Transportation Management Systems (TMS) \\
\hline 8. & Radio Frequency (RF) systems \\
\hline 9. & Geo-coded Tracking \\
\hline 10. & Bar coding technology \\
\hline 11. & Electronic Commerce Technology \\
\hline
\end{tabular}

technology systems they have to choose between 1 (not adopted at all) to 5 (fully adopted). We generate a new variable that expresses the degree to which each company has adopted technology systems. For this purpose, we added the 11 independent items and we create a new variable, named 
technology systems adoption, with possible values between 11 and 55. The mean value of this new variable is 35.06 (standard deviation 9.9) and median 34.5.

The digitalization of the company is expressed by 12 items about supply chain in section $\mathrm{D}$, as presented in Table 3.

Table 3. Items of section D

\begin{tabular}{|l|l|}
\hline \multicolumn{1}{|l|}{$\#$} & \multicolumn{1}{|c}{ Item } \\
\hline 1. & Warehouse Robotics in the Supply Chain \\
\hline 2. & Increased Focus on Cost-to-serve \\
\hline 3. & More Things Will Connect to the IoT \\
\hline 4. & Autonomous Road Transportation \\
\hline 5. & The Appeal of Supply Chain Social Responsibility \\
\hline 6. & Big Data and Advanced Analytics in the Cloud \\
\hline 7. & Everything as a Service \\
\hline 8. & The Rise of the Virtual Logistics Team \\
\hline 9. & Elastic is the New Lean \\
\hline 10. & The Blurred Line Between Logistics and Technology Services \\
\hline 11. & Perfect Order Will be a Big Deal \\
\hline 12. & Enterprise Mobility Penetration into the Supply Chain \\
\hline
\end{tabular}

In order to identify patterns in the relationships between these items, a principal component analysis (PCA) was conducted on the 12 items with orthogonal rotation (varimax). During the analysis, in sequential steps we drop out items 6,7 and 11 because in the first one the value of Measure of Sampling Adequacy in the Anti-image Matrix was very low (0.422) and the maximum component value in the corresponding table was 0.386 , while in the other two the maximum value of the component in the corresponding table was 0.381 and 0.401 . The Kaiser-Meyer-Olkin measure verified the sample adequacy for the analysis, $\mathrm{KMO}=0.762$, Bartlett's test of Sphericity $\mathrm{x}^{2}(36)=348.919, \mathrm{p}<0.001$, indicated that correlations between items were sufficiently large for PCA. An initial analysis was run to obtain eigenvalues for each component in the data. Three components had eigenvalues over Kaiser's criterion of 1 and in combination explained 58.958\% of the variance. The scree plot showed inflexion that justify retaining of 2 two components in the final analysis.

Finally, the items that cluster on the same components suggested that the first component represents mobility, the second one represents human factor and the third component represents pricing. Items that consist each one of the three components are presented in Table 3.

\subsection{Regression Analysis}

A new variable for each one of the above components, as the average value of the items that consists them is created. These variables are called mobility, human factor and pricing.

Mobility means the use of mobile devices and applications in all aspects of SCM in order to simplify logistics functions and SCM solutions. Human beings run all the activities of SCM. The decisions makers are affected by knowledge, abilities, skills and motivation. Thus, human factor plays an important role in SCM.Supply chain has a big influence on the cost of the final product, thus it is necessary to continually improve the processes within the supply chain and thereby reduce the overall cost. Creative pricing strategies in effective SCM provide opportunities for significant cost reduction. 
We test whether each of the three factors that constitutes digital business, that is mobility, human factor and pricing, is affected by the sector in which companies operate, the number of employees, the way the supply chain is managed, the degree of adoption of technology systems, incoming and outcoming. This is checked with three multiple regression models. To control the sector in which companies operate, the number of employees and how supply chain is managed, dummy variables have been created. More specifically in our sample, the companies come from four sectors, production, packaging, retail and delivery and the way they managed the supply chain has four categories, no management at all, empirically, department of the company and is outsourced. The variable "number of employees" has five values, that is less than 10 employees, between 11 and 30 employees, between 31 and 50 employees, between 51 and 200 employees and more than 200 employees.

Although these techniques were not applied for the analysis of the digitalization of the supply chain so far, it is worth mentioning that regression models identified several factors that directly and positively impact corporate performance (Tan et al., 1999), bivariate correlation and multiple linear regression analysis related the practices and concerns to firms' performance (Zhu et al., 2012), advanced analytics techniques applied to supply chain management and were to descriptive, predictive, and prescriptive analytics (Souza, 2014), statistical methods such as reliability and validity tests and multiple regressions analyzed data and revealed that supply chain management practices have a significant relationship with supply chain performance statically (Sukati et al., 2012).

\section{EMPIRICAL STUDY}

In this section, the results of the regression analysis for the three dependent variables are presented.

\subsection{Dependent Variable Mobility}

In the first regression model, we use mobility as dependent variable. From the final model we excluded the A variable because it was found to be not significant at $5 \%$ level (t-statistic $=-0.599, \mathrm{p}$-value $=$ $0.55)$. The model that will be adjusted is:

$$
\begin{aligned}
& \text { Mobility }=b_{0}+b 1 * \text { techno } \log y \text { systems adoption }+b_{2} * B+b_{3} * \text { retail } \\
& +b_{4} * \text { packaging }+b_{5} * \text { distribution }+b_{6} * \text { no management } \\
& +b_{7} \text { empirically management }+b_{8} * \text { department of the company }
\end{aligned}
$$

The checking for collinearity was done through the VIF test. All VIF values are lower than 5, thus we can safely conclude that collinearity is not a problem for our model. The value of Durbin-Watson test is 1.601 , very close to value 2 thus the condition of independent errors is satisfied. Regression is significant at $5 \%(\mathrm{~F}(8.199)=15.915$, p-value $<0.001)$. Test for normal error distribution (Normal Probability Plot) showed that errors follow the normal distribution (Figure 1). Test for stable variance of the residuals showed that there is steady variation (Figure 2).

The final model is:

$$
\begin{aligned}
& \text { Mobility }=4.074+0.028 * \text { techno } \log y \text { systems adoption } \\
& -0.521 * B-0.439 * \text { retail }+0.262 * \text { packaging }-0.374 * \text { distribution } \\
& +1.346 * \text { no management }-0.450 * \text { empirically management } \\
& -0.043 * \text { department of the company }
\end{aligned}
$$

The coefficients of this model are presented in Table 4.

We notice that: 
Table 4. The coefficients of the model with mobility as dependent variable

\begin{tabular}{|l|l|l|l|l|l|l|}
\hline \multirow{2}{*}{} & \multicolumn{2}{|c|}{$\begin{array}{c}\text { Unstandardized } \\
\text { Coefficients }\end{array}$} & \multirow{2}{*}{ Sig. } & \multicolumn{2}{c|}{ Collinearity Statistics } \\
\cline { 2 - 5 } & B & Std. Error & & & Tolerance & \multicolumn{2}{c|}{ VIF } \\
\hline (Constant) & 4.074 & .335 & 12.162 & .000 & & \\
\hline Technology_systems_adoption & .028 & .006 & 4.675 & .000 & .721 & 1.387 \\
\hline B-Outcoming & -.521 & .075 & -6.928 & .000 & .933 & 1.072 \\
\hline Retail sales & -.439 & .137 & -3.213 & .002 & .820 & 1.220 \\
\hline Packaging & .262 & .251 & 1.046 & .297 & .921 & 1.086 \\
\hline Distribution & -.374 & .144 & -2.593 & .010 & .892 & 1.121 \\
\hline Minimum management of supply chain & 1.346 & .425 & 3.169 & .002 & .705 & 1.418 \\
\hline Empirical management & -.450 & .198 & -2.278 & .024 & .265 & 3.778 \\
\hline Management Department of the company & -.043 & .189 & -.228 & .820 & .278 & 3.596 \\
\hline
\end{tabular}

Figure 1. Normal probability plot for mobility

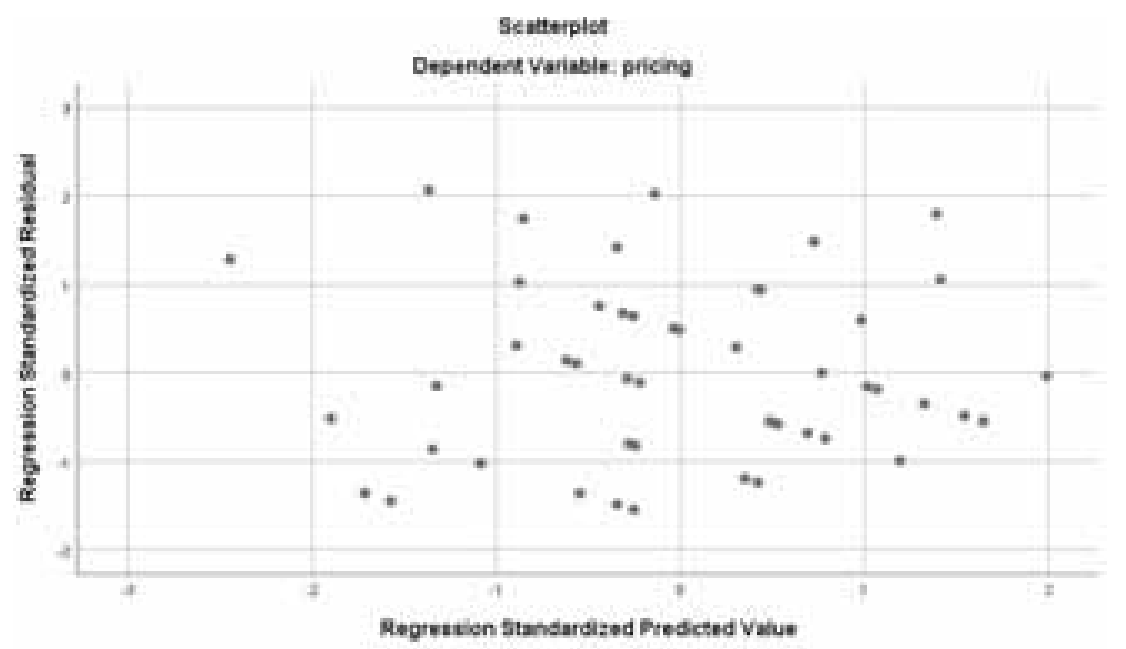

1. For each unit growth of technology_systems_adoption, the mobility increases by 0.028 units;

2. Retail and distribution companies have a lower average of mobility than those involved in the production;

3. By increasing the score on factor B (Outcoming) leads to a decrease in the average mobility;

4. Companies that do not manage the supply chain are more mobile than those outsourced, while those who managed supply chain empirically have lower mobility than outsourced.

\subsection{Dependent Variable Human Factor}

In the second regression model we use human factor as dependent variable. We excluded the A variable from the final model because it was found to be not significant at 5\% level (t-statistic = 1.259 , p-value $=0.21$ ). The model that will be adjusted is: 
Figure 2. Test for stable variance of the residuals for mobility

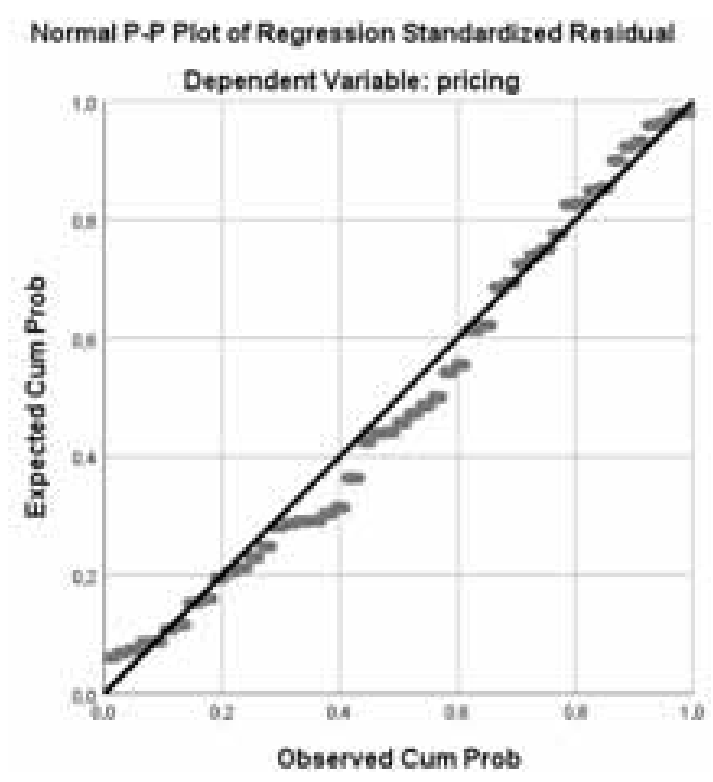

human factor $=b_{0}+b_{1} *$ technology systems adoption $+b_{2} * B+b_{3}^{*}$ packing $*$ $+b_{4} *$ retail $+b_{5} *$ distribution $+b_{6} *($ Employees $<10)+b_{7} *($ Employees $11-30)$ $+b_{8} *($ Employees $31-50)+b_{9} *($ Employees $51-200)+b_{10} *$ Empirically management $)$

The checking for collinearity was done through the VIF test. All VIF values are lower than 5 , thus we can safely conclude that collinearity is not a problem for our model. The value of Durbin-Watson test is 1.762 , very close to value 2 thus the condition of independent errors is satisfied. Regression is significant at $5 \%(F(10.199)=29.674, p$-value $<0.001)$. Test for normal error distribution (Normal Probability Plot) showed that errors follow the normal distribution (Figure 3). Test for stable variance of the residuals showed that there is steady variation (Figure 4).

The final model is:

human factor $=4.252+0.018 *$ technology systems adoption

$-0.409 * B-0.796 *$ retail $+0.007 *$ packaging $-0.239 *$ distribution

$-0.839 *($ Employees $<10)-0.547 *($ Employees $11-30)-0.323$

$*($ Employees $31-50)+0.100 *($ Employees $51-200)$

$+0.212 *$ Empirically management

The coefficients of this model are presented in Table 5.

We notice that:

1. For each unit growth of technology_systems_adoption, the human factor increases by 0.018 units; 
Table 5. The coefficients of the model with human factor as dependent variable

\begin{tabular}{|c|c|c|c|c|c|c|}
\hline & \multicolumn{2}{|c|}{$\begin{array}{l}\text { Unstandardized } \\
\text { Coefficients }\end{array}$} & \multirow{2}{*}{$\mathbf{t}$} & \multirow{2}{*}{ Sig. } & \multicolumn{2}{|c|}{ Collinearity Statistics } \\
\hline & B & $\begin{array}{l}\text { Std. } \\
\text { Error }\end{array}$ & & & Tolerance & VIF \\
\hline (Constant) & 4.252 & .291 & 14.637 & .000 & & \\
\hline Technology_systems_adoption & .018 & .004 & 4.520 & .000 & .563 & 1.776 \\
\hline B-Outcoming & -.409 & .052 & -7.875 & .000 & .654 & 1.529 \\
\hline Retail sales & .007 & .158 & .045 & .964 & .772 & 1.296 \\
\hline Packaging & -.796 & .083 & -9.631 & .000 & .747 & 1.338 \\
\hline Distribution & -.239 & .090 & -2.652 & .009 & .763 & 1.311 \\
\hline Employees $<10$ & -.839 & .173 & -4.839 & .000 & .230 & 4.349 \\
\hline Employees 11-30 & -.546 & .143 & -3.827 & .000 & .315 & 3.173 \\
\hline Employees 31-50 & -.323 & .125 & -2.593 & .010 & .237 & 4.216 \\
\hline Employees 51-200 & .100 & .153 & .652 & .515 & .326 & 3.071 \\
\hline Empirical management & .212 & .067 & 3.172 & .002 & .775 & 1.290 \\
\hline
\end{tabular}

Figure 3. Normal probability plot for human factor

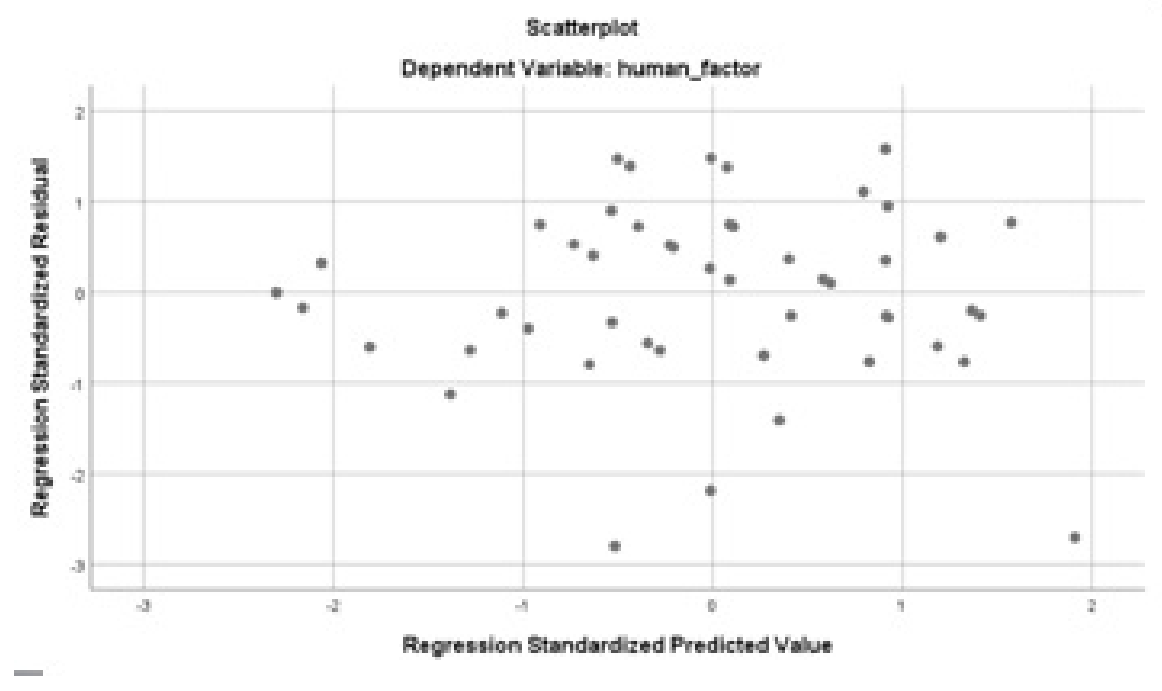

2. Retail and distribution companies have a lower average of human factor than those involved in the production;

3. By increasing the score on factor B leads to a decrease in the average human factor;

4. Companies that manage empirically the supply chain have higher score in human factor than all other companies;

5. Companies that have less than 50 employees have lower score in human factor than these companies with more than 200 employees. 
Figure 4. Test for stable variance of the residuals for human factor

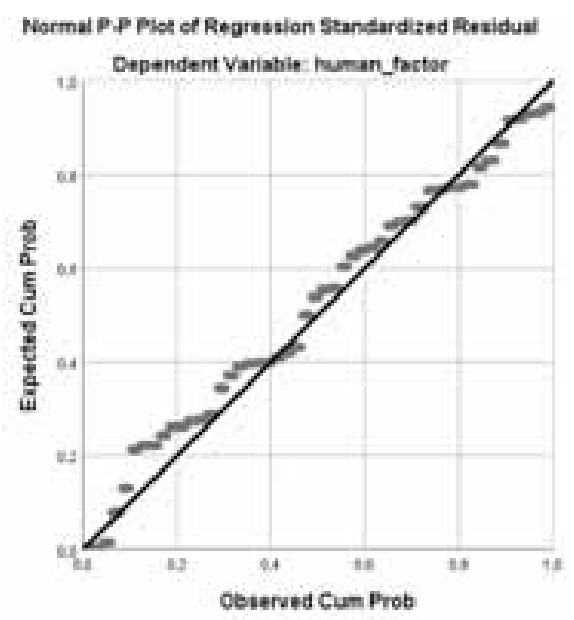

\subsection{Dependent Variable Pricing}

In the third regression model, we use pricing as dependent variable. From the final model we excluded the A variable and the dummy variables related to the number of employees because they were found to be not significant at $5 \%$ level. The model that will be adjusted is:

pricing $=b_{0}+b 1^{*}$ no management of supply chain

$+b_{2} *$ Empirically management $+b_{3} *$ Department of the company

$+b_{4} *$ packaging $+b_{5} *$ retail sales $+b_{6} *$ distribution

$+b_{7} * B+b_{8} *$ technology_systems_adoption

The checking for collinearity was done through the VIF test. All VIF values are lower than 5, thus we can safely conclude that collinearity is not a problem for our model. The value of Durbin-Watson test is 1.804 , very close to value 2 thus the condition of independent errors is satisfied. Regression is significant at $5 \%(F(8,199)=9.718$, p-value $<0.001)$. Test for normal error distribution (Normal Probability Plot) showed that errors follow the normal distribution (Figure 5). Test for stable variance of the residuals showed that there is steady variation (Figure 6).

The final model is:

Pricing $=2.014+1.356 *$ no management of supply chain

$-0.049 *$ Empirically management $-0.023 *$ Department of the company

$+0.728 *$ packaging $-0.478 *$ retail sales $+0.571 *$ distribution

$-0.213 * B+0.033 *$ technology_systems_adoption

The coefficients of this model are presented in Table 6 .

We notice that:

1. For each unit growth of technology_systems_adoption, the pricing increases by 0.033 units; 
Figure 5. Normal probability plot for pricing

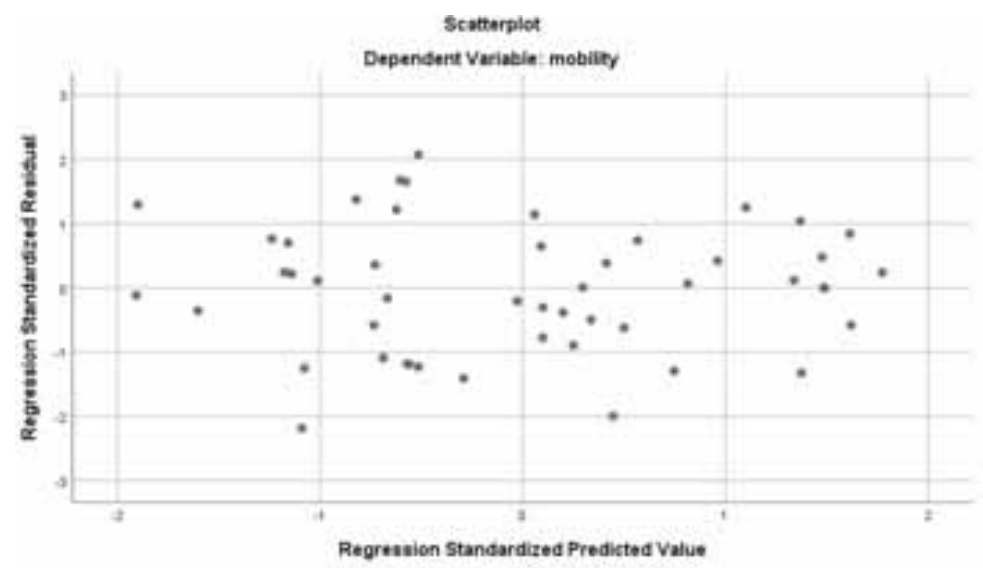

Figure 6. Test for stable variance of the residuals for pricing

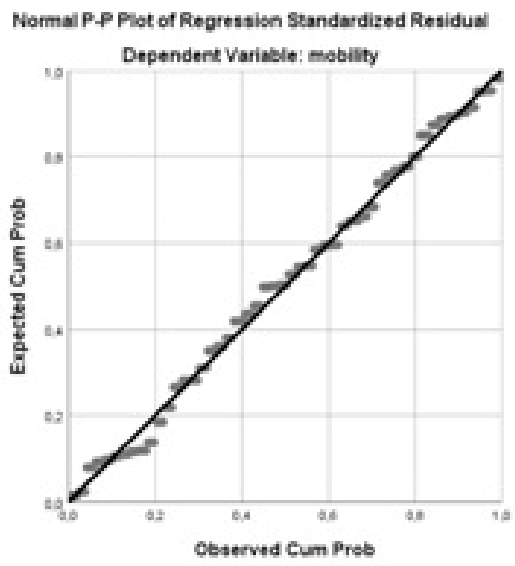

Table 6. The coefficients of the model with pricing as dependent variable

\begin{tabular}{|l|l|l|l|l|l|l|}
\hline \multirow{2}{*}{} & \multicolumn{2}{|c|}{ Unstandardized Coefficients } & \multirow{2}{*}{ t } & \multirow{2}{*}{ Sig. } & \multicolumn{2}{|c|}{$\begin{array}{c}\text { Collinearity } \\
\text { Statistics }\end{array}$} \\
\cline { 2 - 4 } & \multicolumn{1}{|c|}{ Std. Error } & & & Tolerance & VIF \\
\hline (Constant) & 2.014 & .338 & 5.960 & .000 & & \\
\hline Minimum management of supply chain & 1.356 & .413 & 3.284 & .001 & .705 & 1.418 \\
\hline Empirically management & -.049 & .192 & -.256 & .798 & .265 & 3.778 \\
\hline Management department of the company & -.023 & .184 & -.124 & .901 & .278 & 3.596 \\
\hline Packaging & .728 & .133 & 5.483 & .000 & .552 & 1.811 \\
\hline Retail sales & -.478 & .260 & -1.842 & .067 & .813 & 1.229 \\
\hline Distribution & .571 & .172 & 3.313 & .001 & .591 & 1.693 \\
\hline B-Outcoming & -.213 & .073 & -2.918 & .004 & .933 & 1.072 \\
\hline Technology_systems_adoption & .033 & .006 & 5.778 & .000 & .721 & 1.387 \\
\hline
\end{tabular}


2. Packaging and distribution companies have a higher average of pricing than those involved in the production;

3. By increasing the score on factor B (outcoming) leads to a decrease in the average pricing;

4. Companies that do not manage the supply chain have higher score in pricing than companies that use outsource.

\section{DISCUSSION AND CONCLUSION}

This study explored the supply chain management executives' attitudes towards the use of trends and technologies in supply chain. Executives' attitudes towards the use of trends and technologies such as elastic, cost-to-serve, autonomous road transportation, mobility, IoT, Robotics, in supply chain are affected by the type of company, year of establishment, number of employees and technological infrastructure. The main factors revealed in regression analysis are mobility, human factor and pricing.

Mobile devices and applications are necessary tools. The goal is to get products or goods from one place to another in the most efficient and cost-effective way possible. There are several positions within these fields that focus solely on making the supply chains better and more efficient. With the rise of technology and apps that cater to these needs, companies have been able to equip their employees with ways to improve supply chains no matter if they are in field or in the corporate office. The use of smart phones and their applications allow for more flexibility and better services to the customers. It also saves the company money because it allows the supply chain to be more efficient. This is just the beginning of what this mobility in supply chain change can do for the supply chain world. Mobile technologies are also helping companies to improve communication within their transportation networks and more accurately measure the productivity and efficiency within those networks. Company mobility has come a long way in just a few short years. It's been less than a decade since big-budget, rugged mobile devices began to penetrate the warehouse and transport operations of large companies. Consumers demand results quickly. If a company cannot deliver, they will go to the competitor. All of these points are reasons why mobility in the supply chain is required for more effective managing of supply chains in the field.

The supply chain not only includes the manufacturer and suppliers, but also transporters, warehouses, retailers, and customers themselves. This dynamic environment requires effective communication, team management, and constant lifecycle innovation. Human factors insights in these areas are critical for the effective development of global process networks. Wrong decisions by decision makers leads to insufficient behavior and lower performance not only for the decision maker, but also for other stakeholders along the supply chain.

Customers and consumers are increasingly value driven, hence there is a growing recognition that creative pricing strategies combined with effective supply chain management provide opportunities for significant cost reduction and increased profits. Supply chain processes and activities practically include transportation cost, warehousing cost, inventory cost and packaging cost development. The optimisation opportunities through digitalization can reduce the final product cost.

Technology has become such an integral part of our world. It is not only something that is used for entertainment or daily necessity, it is something that can help businesses complete more work in a more efficient manner. And it is finding its way into all aspects of businesses. It is no surprise, with how quickly technology has taken over our world, that it has become such a necessary tool to grow and maintain a business. It is almost something that must be maintained in order to stay in business. The ways of the past are no longer acceptable.

Digital capabilities are critical to meeting the challenge of digital transformation successfully. Incumbents need to consider and drive this rotation to the new as a conscious and deliberate act of renewing and transforming their core business, while growing into new businesses and services.

The supply chain world, in relative terms, has transformed fairly quickly over the last few decades. Globalization, industry 4.0, the Internet and technological advancement have been the 
driving forces in manufacturing. The low rate of supply-chain digitisation to date has much to do with the capabilities of the technologies that companies have had available until recently. While the transition to digital supply chains is complex, failure to act now will put your company at a severe disadvantage in the future.

The findings may influence companies for resource reallocation and strategically shift resources to create more value and deliver higher returns to shareholders.

This preliminary research could not be considered as an indicative for generalization of results. The sample of respondents is only from one part of Greece. Enlargement and reopening of the investigation in future years will record more accurately the views of executives in order to provide safer conclusions. Future studies should seek a broader set of executives who are responsible for SCM functions. By collecting data from a diverse sample in terms of age, gender and place of work increases the generalizability of the findings. Also, the effects of personality and technical competency on the performance within the supply chain could be investigated. 


\section{REFERENCES}

Accenture. (2017). Digital disruption in freight and logistics. Ready to roll? Available at https://www.accenture. com/t00010101T000000Z_w__gb-en/_acnmedia/PDF-53/Accenture-Digital-Disruption-Freight-Logistics.pdf

Accenture. (2018). How companies can embrace digital disruption. Available at https://www.dilx.co/insights/ how-companies-can-embrace-digital-disruption/

Alicke, K., Rachor, J., \& Seyfert, A. (2016). Supply Chain 4.0-the next-generation digital supply chain. McKinsey. Available at https://www. mckinsey. com/business-functions/operations/our-insights/supply-chain40--the-nextgeneration-digital-supply-chain

Baxter, D. (2016). By Supply Chain Disruption: The Bad, The Ugly, \& The Future, Real-Time Visibility. Available at https://www.supplychain247.com/article/supply_chain_disruption_the_bad_the_ugly_the_future

Brightmore, D. (2018). How companies can embrace digital disruption. Available at https://www. supplychaindigital.com/technology/how-companies-can-embrace-digital-disruption

Bughin, J., LaBerge, L., \& Mellbye, A. (2017). The case for digital reinvention. The McKinsey Quarterly, 2, 1-15.

Capgemini and GT Nexus. (2017). The Current and Future State of Digital Supply Chain Transformation. Available at https://www.supplychain247.com/paper/the_current_and_future_state_of_digital_supply_chain_ transformation

Christopher, M. (2016). Logistics \& supply chain management. Academic Press.

Cox, J. F., III, Blackstone, J. H., Jr., \& Spencer, M. S. (1995). APICS Dictionary. Falls Church, VA: American Production and Inventory Control Society. Inc, 14, 15.

Deloitte's Digital Supply Networks. (2016). The rise of the digital supply network. Available at https://www2. deloitte.com/insights/us/en/focus/industry-4-0/digital-transformation-in-supply-chain.html

EY. (2017). Disruption. Digitalization. Disintermediation. Transportation and logistics in the coming decade. Available at https://www.ey.com/Publication/vwLUAssets/ey-disruption-digitalization-disintermediation/\$File/ ey-disruption-digitalization-disintermediation.pdf

Geissbauer, R., Vedso, J., \& Schrauf, S. (2016). Industry 4.0: Building the digital enterprise. Available at PwC Website: https://www. pwc. com/gx/en/industries/industries-4.0/landing-page/industry-4.0-building-your-digitalenterprise-april-2016. pdf

Gezgin, E., Huang, X., Samal, P., \& Silva, I. (2017). Digital transformation: Raising supply-chain performance to new levels. McKinsey \& Company.

Glas, A. H., \& Kleemann, F. C. (2016). The impact of industry 4.0 on procurement and supply management: A conceptual and qualitative analysis. International Journal of Business and Management Invention, 5(6), 55-66.

Hartmann, B., King, W. P., \& Narayanan, S. (2015, Aug.). Digital manufacturing: The revolution will be virtualized. McKinsey Quarterly.

Herman, M., Pentek, T., \& Otto, B. (2015). Design Principles for Industrie 4.0 Scenarios: A Literature Review. Technische Universität Dortmund. Available at http://www.snom.mb.tu-dort- mund.de/cms/de/forschung/ Arbeitsberichte/Design-Principles-for-Industrie-4_0-Scenarios.pdf

Kersten, W., Blecker, T., \& Ri, C. M. (2015). The Impact of Industry Supply Chain. Academic Press.

Korn Ferry Institute. (2017). The Supply Chain Digital Disruption. Korn Ferry. Available at https://www. kornferry.com/institute/download/download/id/18363/aid/1811

Korn Ferry Institute. (2018). Struggles with the Digital Supply Chain. Available at https://www.kornferry.com/ institute/digital-supply-chain

KPMG. (2018). Transforming for a digitally connected future. Available at https://home.kpmg/content/dam/ kpmg/gr/pdf/2018/06/GM-TL-01066_2018\%20GMO.pdf 
Lambert, D. M. (2008). Supply chain management: Processes, partnerships, performance. Supply Chain Management Inst.

Lapinskaite, I., \& Kuckailytė, J. (2014). The impact of supply chain cost on the price of the final product. Business. Management in Education, 12(1), 109-126.

Maier, R., Passiante, G., \& Zhang, S. (2011). Creating value in networks. International Journal of Innovation and Technology Management, 8(03), 357-371. doi:10.1142/S0219877011002416

McKinsey Special Collection Digital Strategy. (2017). Available at https://www.mckinsey.com/ /media/ McKinsey/Business\%20Functions/Strategy\%20and\%20Corporate\%20Finance/Our\%20Insights/Strategy\%20 and\%20corporate\%20finance\%20special\%20 collection/Final\%20PDFs/McKinsey-Special-Collections_ DigitalStrategy.ashx

Mentzer, J., (2001). Supply Chain management. Sage Publications, Inc.

MHI. (2016). Accelerating Change: How Innovation is Driving Digital, Always On Supply Chains. Available at https://www.mhi.org/publications/report

Morley, M. (2017). How Supply Chains are Embracing Digital Disruption. Available at https://blogs.opentext. com/supply-chains-embracing-digital-disruption/

Peppard, J., \& Rylander, A. (2006). From value chain to value network: Insights for mobile operators. European Management Journal, 24(2-3), 128-141. doi:10.1016/j.emj.2006.03.003

Platform I4.0. (n.d.). Von smarten Objekten und Maschinen. Available at https://www.plattform-i40.de/

Pontius, N. (2017). Transformation via Technology: The Key Drivers of Digital Supply Chain Disruption, Business.com / Technology. Available at https://www.business.com/articles/the-key-drivers-of-digital-supplychain-disruption/

Roblek, V., Meško, M., \& Krapež, A. (2016). A complex view of industry 4.0. SAGE Open, 6(2), 2158244016653987. doi:10.1177/2158244016653987

Santos, F. M., \& Eisenhardt, K. M. (2005). Organizational boundaries and theories of organization. Organization Science, 16(5), 491-508. doi:10.1287/orsc. 1050.0152

Sherer, S. A. (2005). From supply-chain management to value network advocacy: Implications for e-supply chains. Supply Chain Management, 10(2), 77-83. doi:10.1108/13598540510589151

Smith, P. (2018). Supply Chain Digital Disruption - What Does It Mean For "Talent"? Available at https:// spendmatters.com/uk/supply-chain-digital-disruption-mean-talent/

Souza, G. C. (2014). Supply chain analytics. Business Horizons, 57(5), 595-605. doi:10.1016/j. bushor.2014.06.004

Specture Labs. (2018). Available at https://www.specture.com/supply-chain-analytics/

Sukati, I., Hamid, A. B., Baharun, R., \& Yusoff, R. M. (2012). The study of supply chain management strategy and practices on supply chain performance. Procedia: Social and Behavioral Sciences, 40, 225-233. doi:10.1016/j. sbspro.2012.03.185

Tan, K. C. (2002). Supply chain management: Practices, concerns, and performance issues. The Journal of Supply Chain Management, 38(4), 42-53. doi:10.1111/j.1745-493X.2002.tb00119.x

Tan, K. C., Kannan, V. R., Handfield, R. B., \& Ghosh, S. (1999). Supply chain management: An empirical study of its impact on performance. International Journal of Operations \& Production Management, 19(10), 1034-1052. doi:10.1108/01443579910287064

Willems, L., Agrell, P. J., \& Lejeune, C. (2018). On the Supply Chain in the Fourth Industrial Revolution. Academic Press. 
Stavros Valsamidis received a five-year Electrical Engineering Diploma from Department of Electrical Engineering, University of Thessaloniki, Greece, an MSc in Computer Science from University of London, UK and his PhD from the Department of Electrical and Computer Engineering, University of Thrace, Greece. He is an Associate Professor in the Department of Accounting and Finance, International University of Greece, Greece. He is currently the Head of the Department. He has published over 120 refereed papers in international journals and conferences. He is author of one book and co-author of nine books. He has also developed several computer software programs. He writes and presents widely on issues of data analysis, data mining, web applications assessment and digital transformation. 